\title{
CONTRABAND OF GOODS AND CUSTOMS OFFENSE: THE ASSESSMENT OF GLOBAL CHALLENGES AND PROBLEMS FOR UKRAINE
}

\author{
Andriy Voytseshchuk \\ Department for Specialized Training and Canine Services of \\ the State Fiscal Service of Ukraine \\ 13/3 Ternopilska str., Khmelnytskyi, Ukraine, 29018 \\ v_and@i.ua
}

\begin{abstract}
Creation of the effective system of customs inspection and formation of transparent procedures of its realization remain priority for world countries in the context of the qualitative integration into the global economic space and growth of global challenges. Illegal movement of goods and objects in global volumes is a threat for the customs space of all countries of the world, despite the development level. Main global tendencies as to contraband of goods and their movement with customs offenses were explained. Main contraband objects were revealed. It was established, that narcotic means occupy the one of first places among goods of illegal movement. Among narcotic substances cannabis is most required at the illicit market. Illegal trade of fauna and flora objects in the last years resulted to irreversible losses of rare species. Attention is accented on the problem of contrafact goods movement through the customs border. The native legislative practice of contraband regulation and customs offenses was elucidated. The assessment of main types of customs offenses in Ukraine was realized. The ways of counteraction to customs offenses of contraband of goods were determined.
\end{abstract}

Keywords: contraband, canine teams, contrafact goods, Customs Code of Ukraine, customs space, customs house, international trade, international cooperation, customs offense, CITES.

\section{Introduction}

The full and effective integration of countries into the global economic space is impossible without formation of transparent procedures of customs control and inspection passage, effective work of customs bodies, creation of the proper system of control of goods and subjects movement through the state customs border of a country. For the whole world the problem of customs offenses, including contrafact goods movement remain unsolved, despite common initiatives of international organizations and governments of countries. For today, the only legislative regulation of this problem is impossible, although the national customs legislation of most world countries is unified, harmonized, takes into account main international-legal acts. The regulating role of the state and construction of the anti-corruption society, that doesn't create favorable conditions for offenses remain important. In practice are often cases of contraband and customs offenses that create a negative image of a state, threaten its national safety and economy. That is just why the aforesaid problems must be solved taking into account main tendencies of contraband spread and customs offenses in the global scale and in Ukraine.

\section{Analysis of literary data and statement of the problem}

The problematics of customs offenses and goods contraband has an old historic base that is noted by the scientists [9], but under conditions of globalization and integration of countries in the global space, strengthening of their mutual dependence and fight for natural, financial, human resources, these processes gained new signs, so forms of customs offenses changed, illegal markets of goods are forming. Among main subjects of illegal markets, which functioning is a direct threat and challenge for global and national economies, with often movements through the customs border with customs offenses and by the contraband way, narcotic means, wild flora and fauna objects, contrafact goods, cultural values, weapon and explosive substances are separated. The question of contraband of aforesaid goods and movement with customs offenses is a subject of studies of international organizations, research centers and scientists [1-8, 16-19]. The main legislative acts that define the notion of customs offenses and contraband in Ukraine regulate the native practice of disclosure and counteraction to these negative processes in the Customs [10] and Criminal [12] 
codes of Ukraine, adapted to the world practice. Especially, there takes place the process of humanization of the responsibility for offenses in the customs sphere [11, 13], use of modern practices and institutional support of counteraction to these offenses and crimes [17]. But let's note, that separate theses of codes need coordination, especially in the part of decriminalization, because the Ukrainian practice demonstrated the insufficient effectiveness of such [20,21], that is proved by the analysis of indices of the fight with customs offenses and contraband, according to the data of the State fiscal service of Ukraine [15].

Alongside with it, the problem of the assessment of modern tendencies of contraband and customs offenses in Ukraine, taking into account global challenges, remains beyond attention.

\section{Aim and tasks of research}

The aim of the work is the assessment of existing tendencies of goods contraband and customs offenses in the global dimension and determination of problems for Ukraine.

For attaining the research aim, the following tasks were set:

- to reveal main global tendencies and challenges of separate goods movement by the illegal way with customs offenses;

- to analyze the legislative base of Ukraine as to counteraction to customs offenses and contraband and to analyze existing problems;

- to offer arrangements, directed on decreasing cases of customs offenses and contraband, their disclosure.

\section{Materials and methods of research}

In the process of the research for attaining the set aim and defined tasks the abstract-logic and historical methods, analysis, synthesis, comparison, theoretical generalization were used.

The information and statistic base of the research is scientific achievements of scientists in this problematics; materials and analytic reports of international organizations and research agencies; official data of the State fiscal service of Ukraine; international and normative-legal acts on questions of contraband and customs offenses prevention.

\section{Results of research}

Under conditions of globalization, questions of strengthening state positions in the support of transparency of external economic relations and customs space, ensuring its safety and using protective instruments against the illegal goods and subjects' movement through the customs border, introducing preventive arrangements are urgent. Among threats of the illegal movement remain narcotic means, weapon, explosive substances, wild fauna and flora objects, contrafact goods, cultural values and so on that have place in all countries of the world.

The illegal production and trade of narcotic means remains the main component of the world illegal trade, despite the constructed international system of control. Thus, the tendency of drugs spreading in the world is kept $[1,2]$. In 2014 cannabis was the main object of the narcotic business (Fig. 1). Let's note, that the main ways of narcotic means movement remain stable, because this business has gained the global expansion through the corruption component.

The illegal international trade of wild flora and fauna objects (together with other unfavorable factors) led to the fact that in the last decades almost a half of its rare species were lost. The legal system CITES is a base of the development of regulation of the international trade of wild flora and fauna objects [3], because, according to different calculations, the illegal trade of these goods varies within $6 \mathrm{n} 20$ bil of USA dollars annually. The regulation of this trade sector is necessary, taking into account volumes of the illegal trade of species that are disappearing or are on the boundary of disappearance, and already existing, well ordered movement channels (Fig. 2). The list of fauna and flora representatives that need a special control at passing the border was formed correspondingly. The acquaintance with this list is extremely important at transporting goods through the customs border, and the revelation of facts of customs offenses depends on the degree of customs officers' acquaintance with the classification of animals and plants by typical signs, licensing documents, necessary for transportation. 


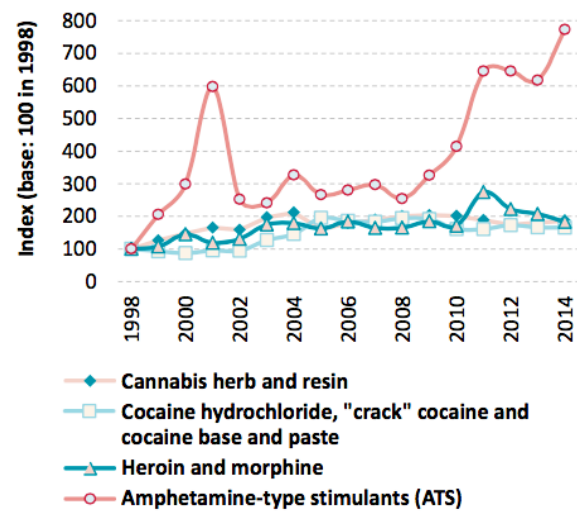

Fig. 1. The dynamics of volumes of drugs confiscation in the world, 1998-2014 [2]

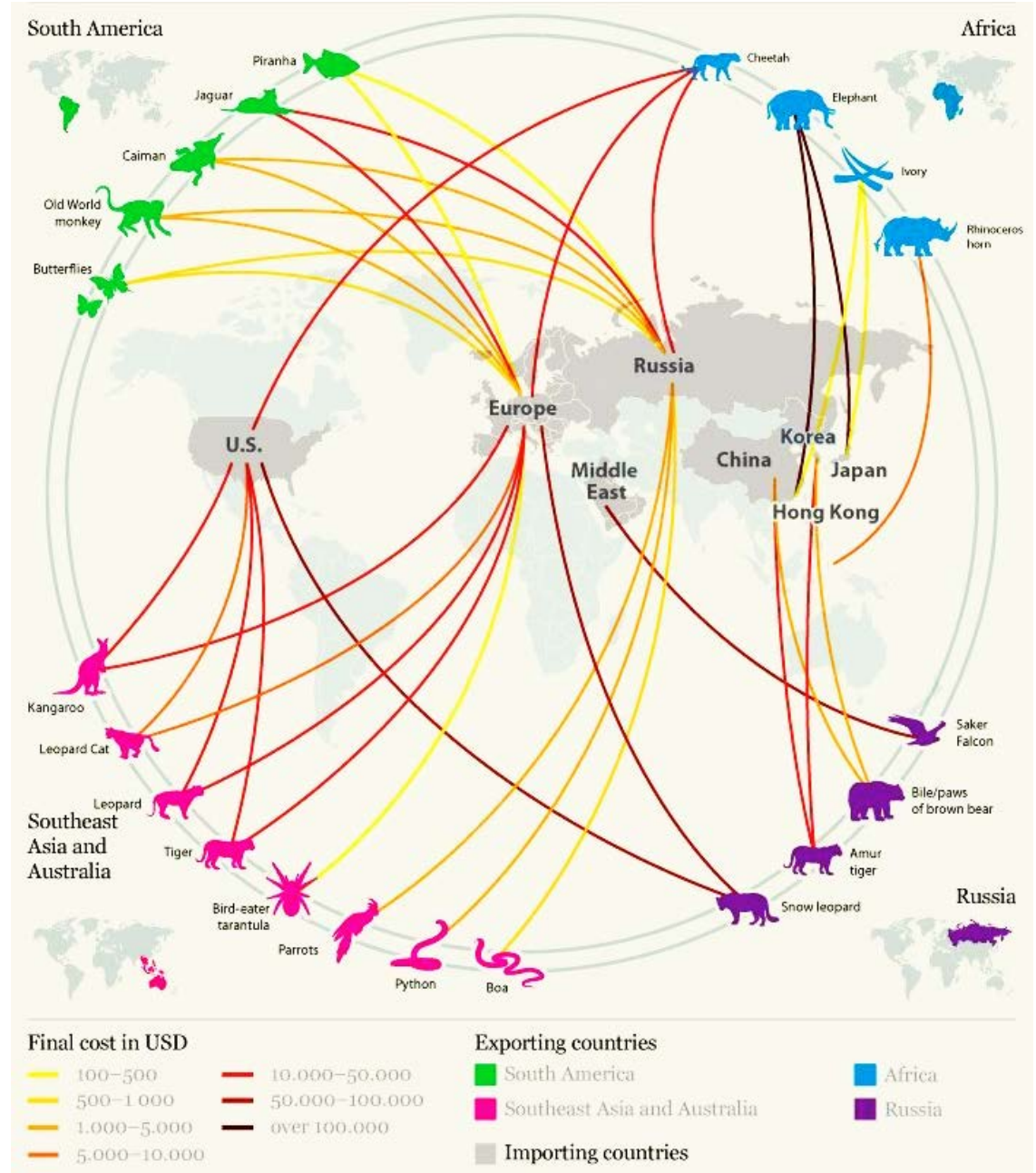

Fig. 2. Contraband routes of the illegal international trade of rare species of flora and fauna [4]

For today five institutions - the United Nations Office on Drugs and Crime (UNODC), the Secretariat of the Convention on International Trade in Endangered Species of Wild Fauna and Flora (CITES), the International Criminal Police Organization (INTERPOL), the World Bank and the World Customs Organization - form the International Consortium on Combating Wildlife Crime (ICCWC). The transportation and rare flora and fauna species through the customs border is realized by hiding from control, documents falsification, beyond pass zones, as the open transportation, connected with the insufficient knowledge of customs workers. This is just why the important 
accent is put on the professional training of persons, who realize the control of legality of goods transportation through the customs border, and learning seminars by international organizations and learning courses and interactive trainings within national institutions are realized for this aim.

The trade of contrafact goods and their transportation through customs borders is a component of the business of international criminal groups and a factor that strengthens corruption in state power authorities. Together with it, importation of such products together with financial and economic risks, brings also a series of others, no less important: danger for human life and health, negative ecological results [5].

The protection of intellectual property right at goods transportation though the customs border of countries remains urgent. Thus, for example, in 2013 the trade of contrafact goods was 2,5\% of the world trade (1,9\% of import); $5 \%$ of the general export of goods in EU - contrafact products; among most spread cases of disclosed contrafact goods - footwear, cloth, leather products (Table 1); in the sphere of the international trade of informational-communicational technologies, contrafact goods were 6,5\% in 2013 (Fig. 3), and in the cost dimension it is near 143 bil of USA dollars. The doubtless leader in these goods production is China, and goods of Americal companies are falsified most often. The problem of the customs regulation of contrafact goods transportation is in fact that the most half of them comes through international post and express parcels $(62 \%$ of all disclosed transportation facts) that complicates control possibilities.

Table 1

The dynamics of contrafact goods confiscation (by HS) [6]

\begin{tabular}{cccc}
\hline HS code & $\mathbf{2 0 1 1}$ & $\mathbf{2 9 1 2}$ & $\mathbf{2 0 1 3}$ \\
\hline Machinery and mechanical appliances (84) & 2423 & & 5722 \\
Instruments, optical, medicaletc. (90) & 3013 & 4960 & 2444 \\
Pharmaceuticals (30) & 3557 & 3789 & 4857 \\
Perfumeryandcosmetics (33) & 3898 & 5837 & 3499 \\
Watches (91) & 7267 & 10214 & 5601 \\
Toys (95) & 7661 & 5560 & 17960 \\
Articles of leather (42) & 7770 & 9772 & 17995 \\
Clothing, knitted or crocheted (61) & 15898 & 18257 & 21076 \\
Electrical machinery and equipment (85) & 16402 & 20476 & 2719 \\
Footwear (64) & 22513 & 26967 & 2419 \\
Jeadgear (65) & & 34938 & 2415
\end{tabular}

Assessing the state of openness of national economies-trade partners in the international trade and defense of intellectual property rights, the Office of trade representatives of the USA (USTR) in 2017 published the annual Report-301,where the first place by the priority of observation as to contrafact goods was occupied by China. Despite certain positive shifts in the policy of counteraction to contrafact goods transportation, Ukraine still be in the priority observation because of the following causes: the use of non-licensed software in the system of state authorities; non-transparent and inequitable system of right-owners' protection; incapable system of the fight with online violations of author rights and so on [7]. The last years the threat of illegal importation of contrafact pesticides grows, including in Ukraine. That is why the counteraction of such customs offense is possible only on the base of the improvement of the system of risks analysis and introduction of correspondent risk profiles; creation of modern customs laboratories; realization of the explaining 
work and teaching workers of customs and border services, directly involved in the process of these goods passage through the customs border; limitation of pass points of pesticides and dangerous wastes, tracing of criminal groups, involved into chains of contrafact goods supply and so on.

Video games consoles and controllers

Sound apparatus

Mobile phones; parts and accessories

Memory cards and sticks; Readers and adapters

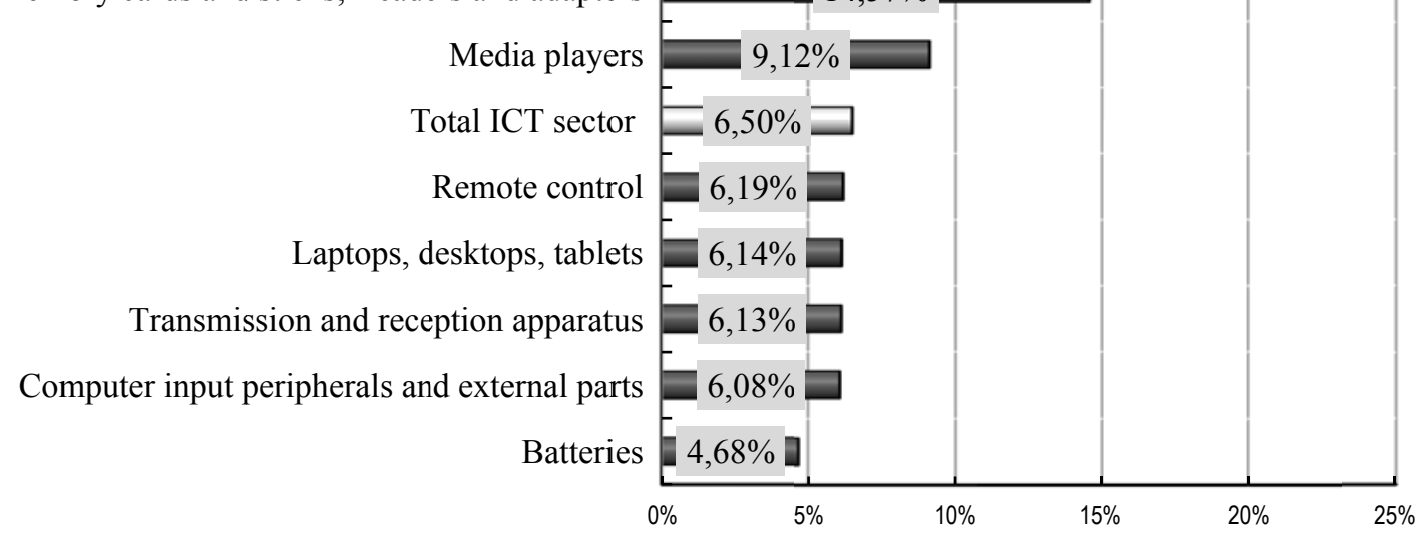

Fig. 3. The part of contrafact ICG in 2013

(\% of the general import volume of each type of good) [6]

The world market of weapon remains the least studied, because its illegal element is formed of so-called "grey" and "black" markets, it is extremely difficult to calculate volumes of weapon supply because of them. Taking into account the growth of politic tension and terrorist threats in the world, nidi of military confrontations and conflicts, the illegal segment of the weapon market is $5 \%$ of the legal one.

The illegal trade of cultural values, where criminality gained the transnational character, remains among priority ones [8], that is why, from our point of view, the main ways of counteraction are: disclosure of facts of values illegal transportation through the customs border; prevention of their removal from countries and territories that are in zones of military and armed conflicts; prevention of documents and cultural values falsification, larcenies, illegal excavations and so on.

The integration of Ukraine in the global trade and European economic space became a push to the implementation of international and European standards into customs offices activity, that is why it is important to unify the legislation as to goods and subject movement through the customs border, support of partner relations with competent organs that realize counteraction to customs offenses and contraband.

The studies prove that contraband has deep historical-legal roots [9]. The native legislation as to customs offenses and contraband underwent changes the last years. Thus, according to paragraph 458 of the Customs code of Ukraine, customs offenses are defined as "illegal, guilty actions or inactivity that violate the established order of transportation goods, transport means of commercial destination through the customs border of Ukraine, their presentation to income and charges authorities for customs control realization and customs clearance and also operations with goods under customs inspection" [10]. The main types of customs offenses are established by paragraphs 468-485 of the Customs Code of Ukraine, and administrative responsibility is provided for them. At to the contraband interpretation, according to the Law of Ukraine "On introduction of changes to several legislative acts of Ukraine as to humanization of the responsibility for violations in the economic activity sphere" decriminalization of the goods contraband took place in 2012 [11]. That is why illegal actions, earlier qualified as contraband, were included to customs rules. Instead of it, paragraph 201 of the Criminal code of Ukraine interprets contraband as the illegal goods trans- 
portation through the Ukrainian customs border that it beyond the customs control or with hiding from it, realized in large scales. The subjects of contraband are historical and cultural values; toxic, potent, radioactive or explosive substances; weapon and ammunition (except smoothbore hunting weapon and its ammunition); strategically important raw materials (for example, subjected to the regime of licensing and quoting of external economic operations) [12]. The customs code presupposed arrangements as to counteraction and prevention of contraband (in the case of controlled supply of narcotic means, psychotropic substances and precursors and also goods movement under the secret control (pp. 456-457) [10] (in January-February of 2016 customs offices realized 51 controlled supply). The positive moment in the new Customs Code, from our point of view, is a possibility of using the peace agreement at disclosure of customs offenses (when criminal law infringement signs are absent), especially it is regulated by paragraph 521 through the conclusion of a peace agreement between a person, who committed a law infringement and incomes and charges body [10]. Such use of the legal compromise in the customs sphere is justified, because its gives a possibility of economy de-shading, realizes the regulatory function and is directed on the solution of conflict situations [13].

It must be noted, that the positive moment for today, from our point of view, is the introduction of changes to p. 201 of the Criminal code of Ukraine as to the determination of the subject of the actual crime, namely: the first part of the paragraph was added with the words "parts of rifled firearm" [14]. Before the activation of changes to the Criminal code of Ukraine (defined by the Law of Ukraine of 18.05.2017 No. 2052-VIII) at disclosing parts of rifled firearm by officers of SFS customs houses (with hiding or beyond the customs control) infringer's actions were not considered as a crime, so this action was qualified as a law infringement. Although the social danger was rather high, because parts of rifled firearm bring the analogous threat to human life and health like an arm itself.

In 2016 customs offices of the State fiscal service of Ukraine disclosed 23235 customs offenses (for over 2 bil hrn.), adjudged 12839 cases about customs offenses, by 7952 cases were temporarily confiscated subjects of law infringements with the total cost $627 \mathrm{mln}$ hrn, especially, industrial products $(353 \mathrm{mln}$ hrn $)$, currency $(161 \mathrm{mln} \mathrm{hrn})$, food goods and agricultural products (62 mln hrn), transport means (51 mln hrn) [15]. The cost dynamics of temporarily confiscated subjects of law infringements (Fig. 4) gives grounds for the following conclusions: distinct interconnected trends in customs offenses disclosure by subject groups are absent; most volumes of confiscated subjects for the period 2008-2011 were transport means (most unstable dynamics is typical for them); in the post-crisis period industrial goods transportation with customs offenses was activated; among food goods after the world economic crisis the important part was occupied by tobacco products (thus, in 2009 their part in confiscation cost was 37\%, in $2010-16,1 \%$, $2011-53,3 \%, 2012-45,6 \%, 2013-40,2 \%, 2014-79,8 \%, 2015-23,16 \%$, 11 months of $2016-29,2 \%)$. On the territory of Ukraine tobacco products are manufactured at secret enterprises that avoid taxation. And despite duties as to implementation of the native legislation to EU directives, Ukraine is a leader in the illegal tobacco supply to the EU territory [16].

In 2016 customs offices also transmitted to law enforcement bodies 1613 messages about disclosure of criminal law infringement and crime signs, according to the Criminal code of Ukraine, because they are not authorized to realize inquests in contraband cases, but only disclose a contraband subject. Especially, there were disclosed 1122 cases of transportation of narcotic means, psychotropic substances and precursors, 469 of weapon and ammunition movement through the customs border with customs offenses [15].

According to the data of the State fiscal service of Ukraine for 10 months of 2016 were disclosed 970 cases of illegal transportation of narcotic means, psychotropic substances and precursors (810 cases for the same period of 2015), especially, cannabis - 48,1 kg; cocaine - 11,8 kg; other narcotic means - 5,2 kg, 13457 tablets, 1095 capsules, 82 ampoules; psychotropic substances $-8,4 \mathrm{~kg}$, 30894 tablets, 16350 capsules, 10 ampoules; precursors $-5,6 \mathrm{~kg}, 1801$ tablets, 161 1, 8 capsules, 1 ampoule. Alongside with it to law enforcement bodies were sent 411 messages as to illegal actions by paragraph 350 of the Criminal code of Ukraine, 146 messages - by paragraphs 307, 309. Cases of the arrest of narcotic substances illegal transportations took place on auto transport (488 cases) 
and at post sending (307), much less on railway (92), avian (27), sea transport (22) and at pedestrian passage (34). Canine teams are actively used in the world practice for disclosing customs offenses and contraband subjects. In this direction Ukraine has essential disproportions between customs offices in involvement of working dogs into the customs control procedure, and correspondingly the different effectiveness of customs offenses and contraband subjects' disclosure. For 6 months of 2017 most these facts were disclosed at Lviv customs office (78 cases), Volyn (30), Kharkiv (23), Sumy (17), Transcarpathian (10). The training of canine teams is realized at the base of the Department of the specialized training and canine support of the State fiscal service of Ukraine that is its territorial organ, which tasks include: the improvement of the system of providing canine subdivisions of SFS of Ukraine with staff and working dogs; expertise of existing training programs for cynologists and working dogs; widening of directions of using working dogs for searching weapon, explosive substances, cigarettes, alcohol and other substances; improvement of the system of canine teams use in SFS of Ukraine, especially the system use of experts-cynologists with working dogs at service within the staff at pass points at the customs border and customs control zones; creation and practical use of mobile groups, formed of canine teams; material-technical support of canine teams' activity [17]. On the base of the Department in 2016 was created the Regional canine learning center of the World customs organization.

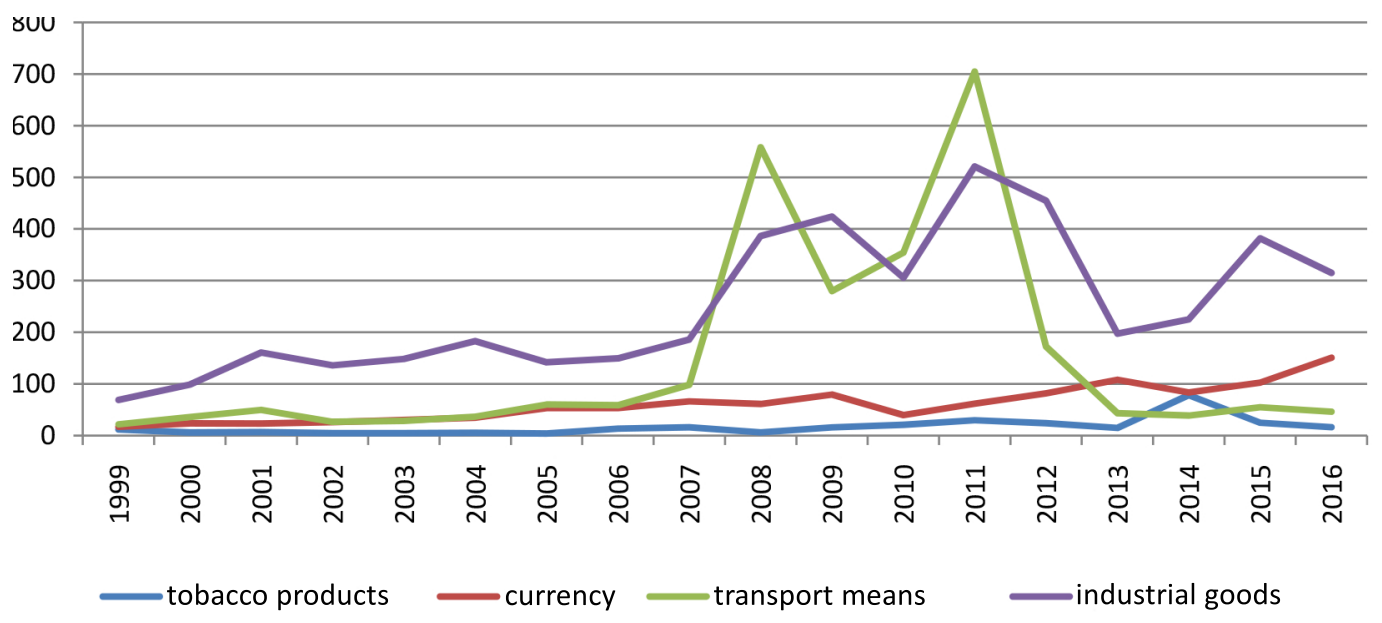

Fig. 4. The cost dynamics of confiscated subjects of customs offenses in Ukraine, mln hrn * Note: made by the author, according to the data of the State fiscal service of Ukraine

Let's note that Ukraine belongs to countries, actively included in global contraband flows of narcotic means [18] and is used as a transit territory for their supply in European Union countries. It is a threat for the safety of EU itself, because, according to different assessments, the retail market of narcotics illegal circulation in the union is assessed as 21-31 bil euro (2013) [19] and, for example, in 2015 were realized 732000 confiscations of cannabis (most part of which is supplied through Spain and Marocco). Such situation needs the improvement of the international cooperation of counteraction to narcotics contrabands, taking into account that Ukrainian territory is included in the route of narcotic means transit movement, including heroin, especially by the "balkanian way".

Alongside with the international cooperation, the State fiscal service and its subdivisions realize thematic seminars and round tables to obtain information about existent problems in customs offenses and prevention directly from territorial bodies' representatives. We think, that among problem questions of customs offices' activity, the ones, directly connected with the absence of the law enforcement status of subdivisions of customs infringement prevention, not only as to contraband subjects disclosure (pp 201 and 305 of the Criminal code of Ukraine [12]), but at service duties realization, for example:

1) inability to obtain information from the State migration service as to registration of citizens at the certain territory, because of the reference to p. 1 of p. 5 of the Law of Ukraine "On 
protection of personal data", pp. 11 and 21 of the Law of Ukraine "On information" and p. 2 of p. 19 of Ukrainian Constitution, are not enough solved. Such approach doesn't allow to realize the control of citizens as to customs legislation offenses, first of all, as a response to demands of customs bodies of foreign countries, institutions and organizations;

2) the problem of the operations information exchange and absence of the distinct coordination between customs offices and law enforcement bodies with its use still be unsolved. Their solution is possible through giving customs offices the status of a "law enforcement" subdivision as to customs offenses and contraband counteraction and introduction of correspondent changes into the legislation.

The problem point is information discrepancy, especially at verifying the reliability of information, given by subjects of the external economic activity there is non-conformity in data, given to the Ukrainian customs office and to the one of a country-importer (exporter) that decreases (increases) the taxation base. The necessity of strengthening of customs and law enforcement bodies' cooperation is accented also by native scientists [20, 21].

Taking into account the numerous cases of customs offenses with transport means movement, the State fiscal service bodies disclose facts of stay of transport means of the foreign registration at the customs territory of Ukraine and also of their use and disposal without a permission of income and charges body, protocols about customs offenses by signs of law infringements, provided by paragraphs 470, 481, 485 of the Customs code of Ukraine [10], where law infringement subjects are passenger transport means of the foreign registration have been composed. Alongside with it, these bodies have no authorities to confiscate law infringement subjects, and these transport means are not moved beyond the territory of Ukraine, so the possible way of such infringements prevention may by the penalty increase and temporary detention or confiscation of a law infringement subject.

The absence of the established term of temporary importation of transport means of commercial destination and responsibility for their violation in the native legislative field remains the one more problem. Thus, paragraph 108 of the Customs code [10] determines that the term of temporary importation of transport means of commercial destination is established by the income and charges body, taking into account that these transport means must be re-exported immediately after the finish of transport operations that they were imported for. Alongside with it, paragraph 481 of the Customs code of Ukraine provides the responsibility for the exceeding of the term of temporary importation or exportation of goods, but according to p. 57 paragraph 4 of the Code transport means of commercial destination don't belong to goods. That is why taking into account the existent practice of customs offenses the text of this point must be added with the words "transport means of commercial destination" And it is also necessary to present part 2 of paragraph 108 of the Customs code in the following edition: "the term of temporary importation of transport means of commercial destination is established by the income and charges body, taking into account that these transport means must be re-exported immediately after the finish of transport operations that they were imported for, but must not exceed 20 days from the moment of importation of transport means of commercial destination, used for goods transportation", without taking into account the time of stay of transport means of commercial destination under customs control in customs zones.

\section{Discussion of results}

The obtained results have the theoretical and practical importance. From the aspect of discovered global tendencies of customs offenses and contraband the research may be in further deepened in the cut of main types of such offenses. The practical importance of the research is in fact that at taking author's offers into account it will be possible to raise the effectiveness of customs offenses and goods contraband prevention in Ukraine.

\section{Conclusions}

The following conclusions may be done as a result of this research:

1. The global problem of illegal trade doesn't lose its urgency, and Ukraine remains an important participants of global schemes of goods illegal transportation, so it is a potential threat for 
its customs space and needs to elaborate effective arrangements for disclosing customs offenses and goods contraband. Modern tendencies of customs offenses and goods contraband are connected with illegal transportation of narcotic means, wild flora and fauna objects, contrafact goods, cultural values. Practically all world countries are involved in these processes.

2. The legislative dysregulation of customs offenses and contraband counteraction in Ukraine was demonstrated. The problems are the absence of "law enforcement" status in customs offices, non-coordination of cooperation between law enforcement and customs bodies as to disclosure of schemes of goods transportation that raises threats and challenges for the customs space.

3. The directions of customs offenses and contraband prevention in Ukraine are not enough effective, so we offer for their improvement: regulation of the information exchange between institutions, involved in customs offenses and contraband counteraction, at the national and international levels; training of specialists, who would master competences and skills of disclosure of contrafact and dangerous goods, identification of goods, prohibited for transportation and so on together with foreign states and international organizations; involvement of canine teams, trained for searching narcotic means, weapon, explosives, CITES subjects in customs control realization, and increase of the number of specially trained working dogs at pass points through the customs border; reduction of the corruption component in customs offices activity and officials that realize the customs control and inspection to the minimum.

\section{References}

[1] World Drug Report 2015 (2015). United Nations Office on Drugs and Crime. Available at: http:// www.unodc.org/wdr2015/

[2] World Drug Report 2016 (2016). United Nations Office on Drugs and Crime, 174. Available at: https://www.unodc.org/doc/wdr2016/WORLD_DRUG_REPORT_2016_web.pdf

[3] Appendices I, II and III (2017). Convention on International Trade in Endangered Species of Wild Fauna and Flora. Available at: https://cites.org/eng/app/appendices.php

[4] Smuggling routes of the illegal wildlife trade (2017). Pinterest. Available at: https://www.pinterest.co.uk/pin/260082947207568309/

[5] The Green Customs Guide to Multilateral Environmental Agreements The Green Customs Initiative (2008). United Nations Environment Programme. Available at: http://wedocs.unep.org/handle/20.500.11822/8771

[6] Trade in Counterfeit and Pirated Goods (2016). Paris: OECD, EUIPO, 136. doi: $10.1787 / 9789264252653$-en

[7] 2017 Special 301 Report (2017). Office of the United States Trade Representative. Available at: https://ustr.gov/sites/default/files/301/2017\%20Special\%20301\%20Report\%20FINAL.PDF

[8] Voitseshchuk, A., Stopenchuk, S. (2016). Risks of moving cultural property across the customs border: challenges for Ukraine. Skhid, 4 (144), 17-22. Available at: http://nbuv.gov.ua/UJRN/Skhid_2016_4_3 doi: 10.21847/1728-9343.2016.4(144).77729

[9] Sasko, E. (2014). Genesis of Criminal Liability for Contraband. History and Law Journal, 1 (3), 107-112. Available at: http://nbuv.gov.ua/UJRN/ipch_2014_1_25

[10] Customs Code of Ukraine (2012). Verkhovna Rada of Ukraine, No. 4495-VI. Available at: http:// zakon2.rada.gov.ua/laws/show/4495-17

[11] Amendments to the Certain Legal Acts of Ukraine on Humanization of Responsibility for Violating Laws of Economic Activity (2011). Verkhovna Rada of Ukraine, No. 4025-VI. Available at: http:// zakon2.rada.gov.ua/laws/show/4025-17

[12] Criminal Code of Ukraine (2001). Verkhovna Rada of Ukraine, No. 2341-III. Available at: http:// zakon2.rada.gov.ua/laws/show/2341-14

[13] Nekyha, S. N. (2013). Compromise is the inherent constituent of the machinery of the law. Journal of Vladimir Vernadsky National University The series on Jurisprudence, 26 (65), 38-44. 
[14] Amendments to the 201 Article of the Criminal Code of Ukraine on the Criminalization of the Contraband Components of Firearms (2017). Verkhovna Rada of Ukraine, 2052-VIII. Available at: http:// zakon3.rada.gov.ua/laws/show/2052-19

[15] Execution of the 2015 Work Programme of State Fiscal Service of Ukraine Annual Report (2016). State Fiscal Service of Ukraine, 95. Available at: http://sfs.gov.ua/data/files/131201.pdf

[16] Project SUN A study of the illicit cigarette market in the European Union, Norway and Switzerland 2015 Results (2016). KPMG, 208. Available at: https://assets.kpmg.com/content/dam/kpmg/pdf/2016/06/ project-sun-report.pdf

[17] Centre for Personnel Professional Development and Cynology of the SCSU. Available at: http:// center.km.ua/index.php/en/

[18] Illicit Trade Report 2015 (2016). World Customs Organization. Available at: https://illicittrade. com/reports/downloads/OMD_ITR_Complete_LR_2016_12_04.pdf

[19] European Drug Report Trends and Developments 2017 (2017). European Monitoring Centre for Drugs and Drug Addiction. Available at: http://www.emcdda.europa.eu/system/files/publications/4541/ TDAT17001ENN.pdf

[20] Avdeev, A. R. (2016). Interaction of Income and Charges with Law Enforcement and Regulatory Agencies in Combating Smuggling of Narcotic Drugs, Psychotropic Substances and Counterfeit Medicines. Lex Portus, 2 (1), 124-149. Available at: http://nbuv.gov.ua/UJRN/LP_2016_2_13

[21] Pryimachenko, D. V. (2014). Information is the form of interaction between state services of income and charges of Ukraine in the process of following procedures of customs. Finance Law, 3 (1), 25-29. 